\title{
The Dynamics of Bugis Diaspora in the Development of Work Migration to Sabah Malaysia
}

\author{
Achmad Zulfikar \\ Perkumpulan Peneliti dan Pemerhati Pekerja Migran Indonesia (P4MIGI) and \\ Department of International Relations Universitas Muhammadiyah Yogyakarta \\ Corresponding author: apa @kabarfikar.com
}

\begin{abstract}
The Bugis are one of the four major tribes in the southern peninsula of Sulawesi Island with majority of their livelihood as a merchants. As merchants, they have to open markets to new areas around the archipelago, even to Malaya peninsula. The existence of the Bugis diaspora in Malaysia was later suspected to be the trigger of other Bugis migrants with one of the reasons to looking for a job. This study uses qualitative research methods with data collection through literature review. The results of this study on the presence of Bugis diaspora in Malaysia present the dynamics in the development of Indonesian migrant workers, mainly from South Sulawesi, Indonesia to Sabah Malaysia. The close relationship of kinship brings the problem of violation of immigration rules which causes the illegal immigrants to be called "PATI" or Unauthorized Foreign Migrants.
\end{abstract}

Keywords: Bugis Diaspora, Work Migration, Indonesian Migrant Workers, South Sulawesi, Sabah Malaysia

\section{Introduction}

The history of human civilization has noted that the process of moving people from one region to another is natural. This is clearly recorded in the term 'nomadic' which means not staying permanently. Nomadic activity is a natural activity carried out by our ancestors and inherited until now, their motivation is to find a place of livelihood to get a place that is considered representative to settle. If this context is brought into the contemporary context, then the motive can be identified is to find a job. When we use the context of antiquity, then cross-border and even the state is not a serious problem. However, entering today, the issue of state boundaries and human movement or known as migration becomes a serious problem handled by the government.

The problem of migration is serious to make this issue an issue that is discussed by all countries and is presented in the United Nations (UN) which is an intergovernmental international organization consisting of 193 countries. In mid-2012, the Secretary General of the United Nations in the General Assembly on International Migration and Development

\footnotetext{
${ }^{1}$ Presented in Joint International Conference 2018 - Diaspora in Transnational Era: Space, Area and Network on February, 22nd 2018. Organized by Parahyangan Centre for International Studies, Parahyangan Catholic University, Indonesia in cooperation with Research Centre for Overseas Korean Business and Culture and BK 21+ Global Diaspora Creative Talent Development Team of Chonnam National University, South Korea.
} 
stated that the growth of international migration since 1990-2010 has increased significantly. He stated, "More people live outside their country of origin today than at any time in history. The global number of international migrants increased from 155 million in 1990 to 214 million in 2010. During that period, the number of international migrants in the more developed regions, or the North, grew by 46 million, or 56 per cent, while the immigrant population in the South increased by 13 million, or 18 per cent. By 2010, almost 60 per cent of all international migrants in the world were living in more developed countries, compared with 53 per cent in 1990". (United Nations, 2012) This data shows there are 155 million people migrating internationally in 1990, while in 2010 increased to 214 million people. In the last 20 years there has been an increase of 59 million people, and if averaged there is an increase in the number of international migrants up to 3 million people per year.

Global commitment intensified to the issue of international migration getting stronger. The United Nations on 19 September 2016 held a High Level Summit to discuss the magnitude of the movement of refugees and migrants with the aim of bringing its member states together more humanist and coordinated. This meeting was the first time the UN General Assembly convened a meeting at the Head of State and Government level in an effort to produce a blueprint for international response to refugees and migrants. This meeting is a momentum to strengthen intergovernmental cooperation for better international migration governance and is a rare opportunity to create a responsive and planned system to respond to the large movement of refugees and migrants. In this meeting as many as $193 \mathrm{UN}$ member states signed an action plan to deal with the massive movement of refugees and migrants called the New York Declaration.

The New York Declaration on Refugees and Migrants is a commitment of nation's leaders to save lives, protect rights and share responsibilities on a global scale. In this meeting, nation leaders from each country will implement this commitment. Refugees, migrants and those who accompany them and their countries of origin and communities who benefit from this commitment. This commitment to refugees and migrants is done in response to the increasing number of international migrants from year to year. It is certainly evocative of the countries of the world to pay attention to this, either as a sending country, a transit country, a receiving country, or a combination of all three, including Indonesia. Head of Diaspora Desk of the Ministry of Foreign Affairs of the Republic of Indonesia, Wahid Supriyadi in an interview quoted from Antara stated that currently Indonesia people who do diaspora is estimated to reach 8-10 million worldwide (Antara News, 2013). 
Migration and diaspora are two very closely related terms with the Bugis. One of the most prominent phenomena in the history of the diaspora in the Indonesian archipelago is the Bugis diaspora in the archipelago since the $17^{\text {th }}$ century that built colonies in eastern Borneo, in southeastern Borneo, Pontianak, the Malay Peninsula, especially in southwestern Johor, and in other areas. The Bugis developed sailing, trading, fisheries, agriculture and plantation. In its development, the Bugis are one of the major tribes in the southern peninsula of Sulawesi Island with majority of their livelihoods as merchants. As merchants, they have to open markets to new areas around the archipelago, even to Malaya peninsula. The spread of Bugis tribe in the archipelago to cross into Malaysia with the main motivation to find a job makes us interested to explore more about how the dynamics of Bugis diaspora in the development of work migration to Sabah Malaysia.

\section{Methods}

This paper used qualitative research methods with data collection through literature review which sources from from journal, book and internet that related toward the issue of diaspora and migration, focusing on the Bugis diaspora in the development of work migration to Sabah Malaysia.

\section{Results and Discussion}

\section{Factors and Motivation of Buginese as Diaspora}

Conceptually, migration is a spatial issue involving movements of people from their residential place to a new destination by crossing administrative borders for a certain period of time. Based on the coverage area, migration can be classified into internal (domestic) and international, and based on the time span, it can be categorized into life-time migration, current migration, and frequent (or circular) migration. Lifetime migrants are those born in a different place than their current place of residence. Current migrants are those who have migrated to a different place in the last five years or similar period. Frequent or circular migrants are those who move many times over a certain period of time. (Bustami, Suyatno and Wekke, 2016)

Moreover, based on the intention to stay, migration can also be grouped into temporary and permanent migration. These different time spans and intents are not strictly or uniformly imposed in the categorization of migration in this paper, as official data are typically very unclear about definitions and criteria. This lack of clarity is unfortunate, since the economic and policy implications for each type and motivation for migration are very 
different. More interestingly, analyses or concerns on migration from the host country perspective often perceive migration as permanent, and as such to be a source of problems (in addition to potential benefits). On the other hand, from the perspective of migrants, migration is often seen as temporary, incorporating the expectation that migrants will return home to bring also the social, political and other remittances (i.e. better knowledge, skill, wider exposure, more experience etc.) in addition to financial flows remitted during the migration period (Guntur Sugiyarto, 2014; Wekke, 2013; Bustami, Suyatno dan Wekke, 2016).

Cohen \& Lemma (2011) stated that migration needs to be understood as one part of a broader set of processes of social transformation, arising from major changes in global, political, economic, and social relationships. The Government Office for Science London (GOSL), has built on these previous frameworks by presenting a conceptual model to understand and assess the contextual effects of the environment and environmental change on human migration. Figure 1 is the original conceptual model from the GOSL (2011). The focus of the model resides with a set of "factors of migration," and how these contextual characteristics may be influenced by climate change (See Figure 1).

Figure 1. The Factors of Migration

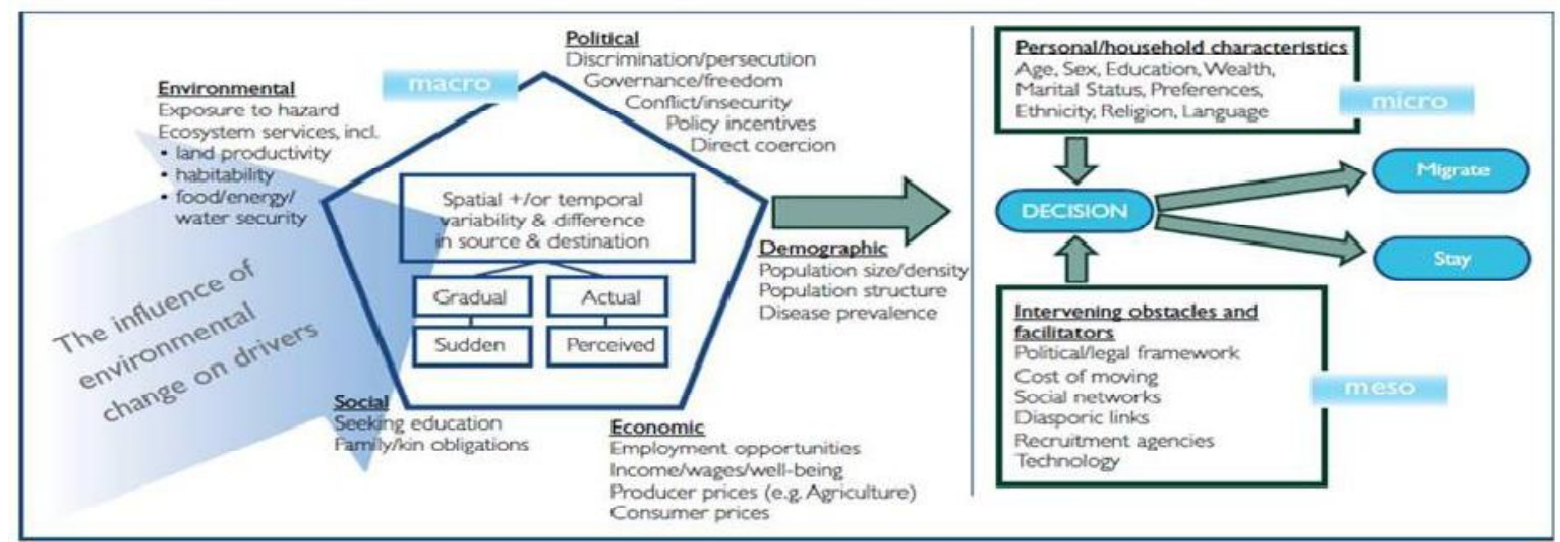

Source: Government Office for Science London (GOSL), 2011

Furthermore to understand this model or this framework, a distinction is to be made between mobility and displacement. Displacement is defined as the movement that occurs in association with discrete events that challenge a household's safety, security, or livelihoods. Displacement is involuntary or forced, often as a result of rapid onset of hazards. Mobility on the other hand is explicated as a proactive move to improve livelihoods and opportunities, is seen as an adaptation, and is typically voluntary and planned (GOSL, 2011). In this framework, the focus is on mobility, the decision of when to move and the motivation for that movement—-the factors that drive migration. 
The five factors of migration, the push-pull factors, as defined in this model include: economic factors, political factors, demographic factors, environmental factors, and social factors. It is the actual or perceived spatial and temporal differences in these dimensions that influence an individual or household's decision to migrate or to stay. Incorporating the spatial and temporal aspects of these dimensions, promotes the idea that a unique set of qualities can exist at any one time in any one context to affect each individual's decision on whether or not to migrate.

This model asserts that the largest effect of social factors is on the destination migrants choose. "Gravity models" of migration indicate that there exists an interaction between economic and social factors as push and pull factors in the decision to migrate (GOSL, 2011). Migration networks-a form of social network, can be formal through agencies, or information through kin networks. Past migration and migration of family members of friends can be a good predictor of future migration. Similarly, remittance flows can aid in the maintenance of family connections as well as provide resources that sustain livelihoods for those staying behind.

Migration for the people of Bugis is a practice that has become one part of their traditions. Philosophically, they look at this tradition as a need for them to hold migrations in order to strengthen their lives. The word "kegisi monro sore lopie, kositu tomallabu se'ngereng" (where there is a boat harbored, there shall be a life to be strengthen). With such word, it is essentially means that there was a long history of experiences from ancestors down to the present traits of families. It is believed by the people of Bugis and that has made the migration itself as a form of a chance to obtain a better living. For that matter, migration activities are part of those various traditions that is not strange anymore, it is also becoming a primary choice and by various reason that reside behind the choice made. Furthermore, with this migration to be held, it symbolizes that in the culture, it has been going on for time to time. (Bustami, Suyatno \& Wekke, 2016)

The above explanation becomes a reference for exploring how the factors and motivations of the Bugis as diaspora are correlated with the dynamics of Bugis diaspora in the development of work migration to Sabah Malaysia. It is also interesting to know that the migration of Bugis tribes who philosophically derived from their belief stems from the principle of seeking a better life. This is also an interesting finding in research on the Analysis of Social, Political and Economic Problems on Migration of Indonesian Migrant Workers Abroad. In general, this study analyzes the social, political and economic problems of work migration abroad. Specifically this study examines the factors that influence the 
intentions of migrant workers migrating permanently abroad, knowing the factors that encourage prospective migrant workers to migrate abroad, seeking solutions to problems often faced by migrant workers or prospective labor migrants and provide recommendations to related parties. (Susilowati, Rahardjo and Waridin, 2001; Zulfikar, 2016)

The results of this study indicate that most prospective migrant workers have not experienced working abroad. Factors hope to find a better job is a dominant factor that causes Indonesian migrant workers (IMW) to go overseas. IMW migrate and work abroad because employment opportunities with suitable results are not widely available in the country. Thus the economic factor is the main determinant for prospective migrant workers and migrant workers to go overseas. While non-economic factors such as seeking work experience abroad and seeking satisfaction ranks lower. There are quite a lot of IMW who do not have adequate skills and knowledge. Due to such conditions many of them are facing problems in the destination country, whether in their relationship with the employer or with the government in the destination country, particularly those concerning the fulfillment of applicable rules of law. (Susilowati, Rahardjo and Waridin, 2001; Zulfikar, 2016)

The estimation result using Binary Logit model can be seen that four factors can influence the intention of the respondent to migrate and work permanently in the destination country. These factors are: marital status and length of stay in the destination country (both including social factors), wages in destination country (economic factors), and overseas work experience as indicated by the number of returning migrant workers to their home areas after working in overseas. While other factors suspected to affect migrant workers' intentions migrating/working abroad, statistically can not explain the phenomenon of intention to permanently reside in the migration destination country. If sorted according to the level of statistical significance, the main determinants that may affect the intentions of migrant workers working abroad are the experience of working abroad, followed by the amount of income, marital status and length of stay in the destination country. The results of the Multinominal Logit model analysis showed that young, low-educated, not frequent and returning migrant workers from fertile areas tend not to intend to settle in the destination country. (Susilowati, Rahardjo and Waridin, 2001; Zulfikar, 2016) The above indicates that the Bugis diaspora also has the potential to experience the same thing as revealed in the results of the study. 


\section{Work Migration of Buginese to Sabah Malaysia}

Actually when discussing human migration from Indonesia to Malaysia, history will be the key witness that the migration process has lasted a long time between these nations. The concept of "Nusantara" (see Anwar, 2016) could perhaps be a measure of human migration due to various factors such as economics and similarities of social measures such as language, culture, and ethnicity. Human migration has increased exponentially in modern times, encouragement by the Information, Communication and Technology (ICT) revolution. (Bustami, Suyatno \& Wekke, 2016)

According to the International Organization for Migration (IOM), the flow of Indonesian domestic workers into Malaysia can be seen as a structural phenomenon driven by economic and demographic disparities within the region. Malaysia is the top destination in Southeast Asia for Indonesian migrants, the majority of whom are women employed as domestic workers, nannies, and elderly care workers (IOM, 2010). Qualitative studies have shown that the main driving factors behind this type of migration are often economic (Ford, 2001; Human Rights Watch, 2005; Anggraeni, 2006; IOM, 2010). Pay differentials provide a strong incentive for these women to migrate abroad in order to improve their livelihoods and social status.

Malaysia has experienced significant labor shortages in the low-wage sector since the late 1970s, owing to its state-led industrialization program - namely, the New Economic Policy (NEP) between 1971 and 1990, and the National Development Policy (NDP) between 1991 and 2000 - which sought to diversify the nation's economy through export promotion and the establishment of an educated workforce (Chin, 2002; Kaur, 2010; Bustami, Suyatno \& Wekke, 2016). In these destination areas, rapid industrialization and an increase in women's participation in the workforce resulted in a steady rise in the number of dual-income families, which was accompanied by a strong demand for migrant domestic workers who served as paid substitutes for the social reproductive labour needed within these middle-class households (Huang \& Yeoh, 1996; Bustami, Suyatno \& Wekke, 2016).

Meanwhile, Indonesia is the biggest country in the region in terms of area, population and labour force. It is also the biggest economy based on GDP. Yet per capita income in Indonesia is considerably lower than in its faster-growing neighbours, Malaysia and Singapore, and this has induced substantial migration from Indonesia to its neighbours. Indonesia is a quintessential labour-surplus nation. At the end of 2006, an estimated 11 per cent of Indonesian workers (11.6 million) were unemployed, and underemployment was over 20 per cent (45 million workers) (Hugo, 2007; Bustami, Suyatno \& Wekke, 2016). This is the 
reason why human migration to Malaysia cannot be avoided since the economic and demographic factors act as a trigger.

Economic reasons drive the majority of Indonesian labor migrants to migrate abroad, to improve the economic status of themselves and their families. High levels of unemployment and underemployment in Indonesia push many individuals to look for jobs outside their area of origin and many may decide to go abroad after hearing about the availability of jobs from recruitment agents and social networks and the higher salaries on offer abroad in countries such as Malaysia, Saudi Arabia, Hong Kong SAR, Kuwait, Singapore and the United Arab Emirates. Many individuals, especially women, see migration abroad as the only way out of poverty for them and their families. Most workers therefore migrate with the intention of working abroad for only a limited period of time in order to save enough money to purchase a house, open a business or send their children or relatives to school. Although labor migration from Indonesia is characterized as temporary because few migrants leave with the intention of settling in the destination country, they generally do not have the opportunity to stay even if they change their mind. Nevertheless, due to the high costs often associated with securing overseas employment, temporary labor migration often turns into a stay that is longer than expected and may last several years. (Bustami, Suyatno and Wekke, 2016)

Another major challenge facing Indonesia and Malaysia is irregular migration. There are several categories of foreigners who can be considered irregular status, and not all of them are migrant workers. Generally, foreign nationals who fall under any of the following categories are classified as "irregular" or "undocumented migrants": (1) unauthorized entry and employment; (2) authorized entry but unauthorized employment; (3) authorized entry and employment but work permits invalidated; (4) refugees; and (5) children of undocumented migrants or refugees born in Malaysia but whose births were not registered with the relevant authorities (Kanapathy, 2008; Bustami, Suyatno \& Wekke, 2016).

Estimating the size of the migrant population in the country is a rather slippery task as the number in irregular status varies drastically. Moreover, defining the term "irregular" or "unlawful" migration itself is fraught with difficulties, especially in the case of Sabah which has a unique migration experience. Official estimates of undocumented migrants in the Peninsula has sunk to as low as 400,000 immediately following an amnesty and subsequent crackdown by the authorities and has peaked to over a million when there is a lapse in enforcement. In a comparative recent period, the estimate of the total number of irregular migrants in Malaysia (mostly from Indonesia and the Philippines) ranges from 600,000 to 1.9 
million (United Nations Office on Drugs and Crime, 2012). There are 300,000-350,000 Indonesian migrant workers in Sabah, $70 \%$ of which are working in plantations and are undocumented. In the first quarters of this decade, Malaysia has some 2.2 million documented foreign workers, almost 20 per cent of Malaysia's workforce. Approximately the same number is undocumented (Trapped the Exploitation of Migrant Workers in Malaysia, 2010). More than 70 per cent of the undocumented workers are from Indonesia. In other words, the incidence of irregular migration in Malaysia is relatively high compare to its neighbours. (Bustami, Suyatno \& Wekke, 2016)

In the initial years, illegal entry and employment was more common, especially among the Indonesians and the Filipinos entering Sabah. However, with the increase in border surveillance, irregular migrants are predominantly those who enter the country lawfully under different visa conditions but overstay. About half of the Indonesians who entered Sabah under a tourist visa between 1996 and February 2003 failed to return home upon the expiry of their visa (Azizah Kassim, 2004; Bustami, Suyatno \& Wekke, 2016). The Malaysian Home Minister estimated that in late 2006 there were around 600,000 unauthorised migrant workers in Malaysia (most of them Indonesians) despite periodic sweeps, deportations, and amnesties. Prospective labour migrants enter Malaysia via ferries leaving Batam in the Riau Archipelago. They gain entry as tourists through Plunggur in the southwest of the Malay Peninsula by showing they have RM1000 (US\$320). There are other points of entry in West and East Malaysia where a similar process applies (Hugo, 2007; Bustami, Suyatno \& Wekke, 2016).

It is clear that migrant workers and irregular migrants, as a result of migrant workers problems, are a result of economical and demographical factors. The amount is so large that it becomes a serious burden for the government of Indonesia and Malaysia. Based on the explanations above, migration to Malaysia is influenced by economics and demographics. To solve this problem, both countries have to involve all stakeholders and society. Sending unprepared workers would create a big problem in the future. On the other hand, Malaysia as a destination country should ban cheap and illegal workers that will increase irregular migrants. Pull and push factors can be used as an effective analysis to capture the problem. (Bustami, Suyatno \& Wekke, 2016)

In addition to migration for work there is also another kind of migrant. These other migrants do so for factors of socio-cultural, environmental or political factors that also influence the two countries. But since the number of migrant workers is very large, it is natural that labour migration dominates the news. To explore factors of migration it is very 
interesting to understand the pattern of migration in Indonesia-Malaysia. Historically, the root of migration between the two countries has been going on for a long time period. This is the reason why discussions about migration between the two countries should include all of the factors of migration in order to get a complete picture of migration (Wekke, 2014; Bustami, Suyatno \& Wekke, 2016).

Bugis tribe as has been explained that the Bugis are one of the major tribes in the southern peninsula of Sulawesi Island with majority of their livelihoods as merchants. However, over time with philosophy "kegisi monro sore lopie, kositu tomallabu se'ngereng" (where there is a boat harbored, there shall be a life to be strengthen) which is believed to be one of the principles of Bugis tribe, the contemporary context means that everything is possible to do to earn a decent living. Thus, one of the professions interested by the Bugis is to become migrant workers or Indonesian Migrant Workers (IMW). This is reflected in the data released by the Center for Service, Placement and Protection of Indonesian Migrant Workers (BP3TKI) Makassar as follows:

Table 1. Placement of IMW based on Regency/City Area of South Sulawesi 2012-2015

\begin{tabular}{|c|c|c|c|c|c|}
\hline \multirow[b]{2}{*}{ No. } & \multirow{2}{*}{$\begin{array}{l}\text { Regency (Kab.) / } \\
\text { City (Kota) }\end{array}$} & \multicolumn{4}{|c|}{ Year } \\
\hline & & 2012 & 2013 & 2014 & $\begin{array}{c}2015 \\
\text { (sd Nov) }\end{array}$ \\
\hline 1. & Kab. Bantaeng & 1.568 & 1.415 & 725 & 293 \\
\hline 2. & Kab. Barru & 77 & 55 & 21 & 4 \\
\hline 3. & Kab. Bone & 158 & 200 & 89 & 32 \\
\hline 4. & Kab. Bulukumba & 1.047 & 869 & 672 & 107 \\
\hline 5. & Kab. Enrekang & 2 & 10 & 20 & 4 \\
\hline 6. & Kab. Gowa & 1.665 & 1.563 & 981 & 263 \\
\hline 7. & Kab. Jeneponto & 577 & 689 & 433 & 147 \\
\hline 8. & Kab. Kep. Selayar & 1 & 7 & 7 & 2 \\
\hline 9. & Kab. Luwu & 21 & 64 & 58 & 7 \\
\hline 10. & Kab. Luwu Timur & 6 & 15 & 14 & 7 \\
\hline 11. & Kab. Luwu Utara & 16 & 48 & 52 & 5 \\
\hline 12. & Kab. Maros & 42 & 71 & 54 & 14 \\
\hline 13. & Kab. Pangkep & 13 & 28 & 26 & 6 \\
\hline 14. & Kab. Pinrang & 126 & 148 & 144 & 75 \\
\hline 15. & Kab. Sidrap & 22 & 27 & 24 & 11 \\
\hline 16. & Kab. Sinjai & 15 & 21 & 15 & 1 \\
\hline 17. & Kab. Soppeng & 335 & 293 & 81 & 56 \\
\hline 18. & Kab. Takalar & 30 & 45 & 41 & 10 \\
\hline 19. & Kab. Tana Toraja & 18 & 23 & 25 & 3 \\
\hline 20. & Kab. Toraja Utara & - & 6 & 18 & 14 \\
\hline 21. & Kab. Wajo & 13 & 18 & 9 & 2 \\
\hline
\end{tabular}




\begin{tabular}{|r|l|r|r|r|r|}
\hline 22. & Kota Makassar & 236 & 664 & 509 & 112 \\
\hline 23. & Kota Palopo & 14 & 56 & 36 & 4 \\
\hline 24. & Kota Pare-Pare & 46 & 25 & 22 & 7 \\
\hline & Total & 6.048 & 6.360 & 4.076 & 1.186 \\
\hline
\end{tabular}

Source: BP3TKI Makassar

The data above represent migrant workers from South Sulawesi where the majority of Bugis are placed through procedures to Malaysia based on the recapitulation of BP3TKI Makassar. While the migrant workers from South Sulawesi are placed into the following countries:

Table 2. Destination Countries of IMW 2012-2015

Area of Work BP3TKI Makassar (Makassar, Pare-Pare, Mamuju)

\begin{tabular}{|c|c|c|c|c|c|}
\hline \multirow[b]{2}{*}{ No. } & \multirow[b]{2}{*}{ Countries } & \multicolumn{4}{|c|}{ Year } \\
\hline & & 2012 & 2013 & 2014 & $\begin{array}{c}2015 \\
\text { (sd Nov) }\end{array}$ \\
\hline 1. & Malaysia & 5.959 & 6.028 & 3.514 & 1098 \\
\hline 2. & Saudi Arabian & 110 & 171 & 231 & 51 \\
\hline 3. & Brunei Darussalam & 55 & 22 & 29 & 4 \\
\hline 4. & Japan & 52 & 69 & 47 & 30 \\
\hline 5. & Singapore & 52 & 230 & 166 & $\overline{14}$ \\
\hline 6. & Hongkong & 21 & 35 & 14 & - \\
\hline 7. & South Korea & 17 & 7 & 9 & 1 \\
\hline 8. & Kuwait & 16 & 17 & 7 & 1 \\
\hline 9. & Uni Arab Emirate & 6 & 66 & 127 & 4 \\
\hline 10. & United States of America & 4 & 27 & 12 & 1 \\
\hline 11. & Cambodia & - & - & - & - \\
\hline 12. & Lao PDR & 2 & 14 & 6 & - \\
\hline 13. & Myanmar & - & 4 & 1 & - \\
\hline 14. & Philippines & - & - & - & - \\
\hline 15. & Thailand & 1 & 24 & 21 & 2 \\
\hline 16. & Vietnam & 2 & 2 & 6 & - \\
\hline 17. & Others & 27 & 234 & 229 & 81 \\
\hline & Total & 6.324 & 6.950 & 4.419 & 1.287 \\
\hline
\end{tabular}

Sumber: BP3TKI Makassar

The data above shows Malaysia as the destination country with the largest number of placements in 4 years (2012-2015). This shows that Malaysia is a favorite destination for migrant workers from South Sulawesi. Malaysia dominates the placement of overseas workers in 2012 (94,2 percent), 2013 (86,7 percent), 2014 (79,5 percent) and 2015 (85,3 percent). When compared to other ASEAN member countries (except Malaysia), Migrant workers from South Sulawesi is also placed to Brunei Darussalam, Singapore and Thailand.

However, migrant workers from South Sulawesi who dominated Bugis tribe seems to contribute the largest in the problem of illegal workers. This can be seen from the data of 
IMW/Indonesian citizen deported due to immigration violation in Malaysia. Data obtained at BP3TKI Nunukan, as follows:

Table 3. IMW/Indonesian Citizens on Deporation based on Sex and Document Category

\begin{tabular}{|r|r|r|r|r|r|r|r|r|}
\hline \multirow{2}{*}{ No } & \multirow{2}{*}{ Year } & \multicolumn{4}{|c|}{ Sex } & \multicolumn{4}{|c|}{ Document Category } \\
\cline { 3 - 10 } & & L & \multicolumn{1}{c|}{$\mathrm{P}$} & Total & Illegal & IMW Case & $\begin{array}{c}\text { General } \\
\text { Case }\end{array}$ & $\begin{array}{c}\text { Border } \\
\text { Case }\end{array}$ \\
\hline 1 & 2012 & 2433 & 703 & 3136 & 2.001 & 369 & 640 & 126 \\
\hline 2 & 2013 & 2355 & 512 & 2867 & 1.620 & 433 & 712 & 102 \\
\hline 3 & 2014 & 2797 & 846 & 3643 & 2.539 & 395 & 650 & 62 \\
\hline 4 & 2015 & 4365 & 1654 & 6019 & 4.091 & 684 & 1153 & 91 \\
\hline \multicolumn{2}{|c|}{ Jumlah } & 11.950 & 3.715 & 15.665 & 10.251 & 1.881 & 3.155 & 381 \\
\hline
\end{tabular}

Source: BP3TKI Nunukan (2016)

The data above shows the number of IMW/Indonesian citizen deported from Malaysia since 2012 until 2015 is significant to reach 15.665 people with 10.251 of them illegal. If it is suppressed then $65.43 \%$ of migrant workers deported are illegal workers. This could be due to many factors, including non-procedural migrant workers.

Figure 2. IMW/Indonesian Citizens from Malaysia 2012-2015

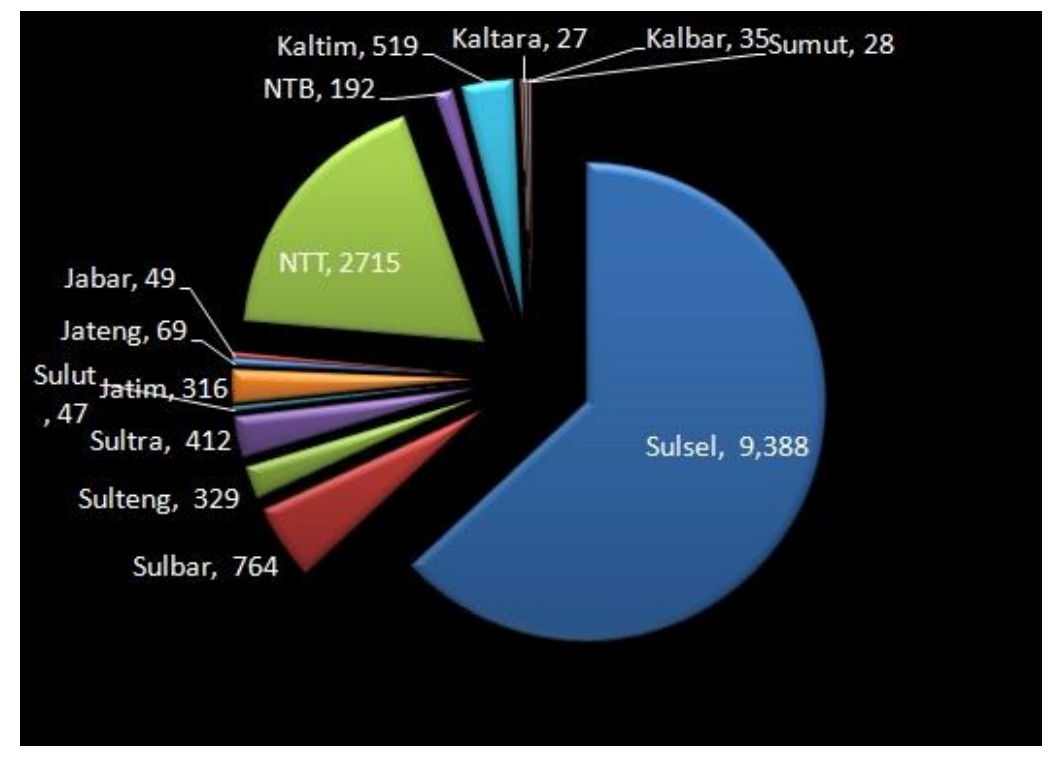

Source: BP3TKI Nunukan (2016)

The data described above is a general overview of work migration conducted by the Bugis to Malaysia. Nevertheless, it is expected that this data exposure can be a concern for academics and policy makers to take systematic and effective steps to ensure that the protection of Indonesian migrant workers can be addressed together. 


\section{The Dynamics of Bugis Diaspora in the Development of Work Migration to Sabah Malaysia}

The Bugis Diaspora as described in the previous section can be analyzed for factors and motivations through the Conceptual Frameworks developed by The Government Office for Science London (GOSL) derived into five factors, including economic factors, political factors, demographic factors, environmental factors, and social factors. A detailed description of each factor contextualized with Bugis diaspora dynamics is as follows:

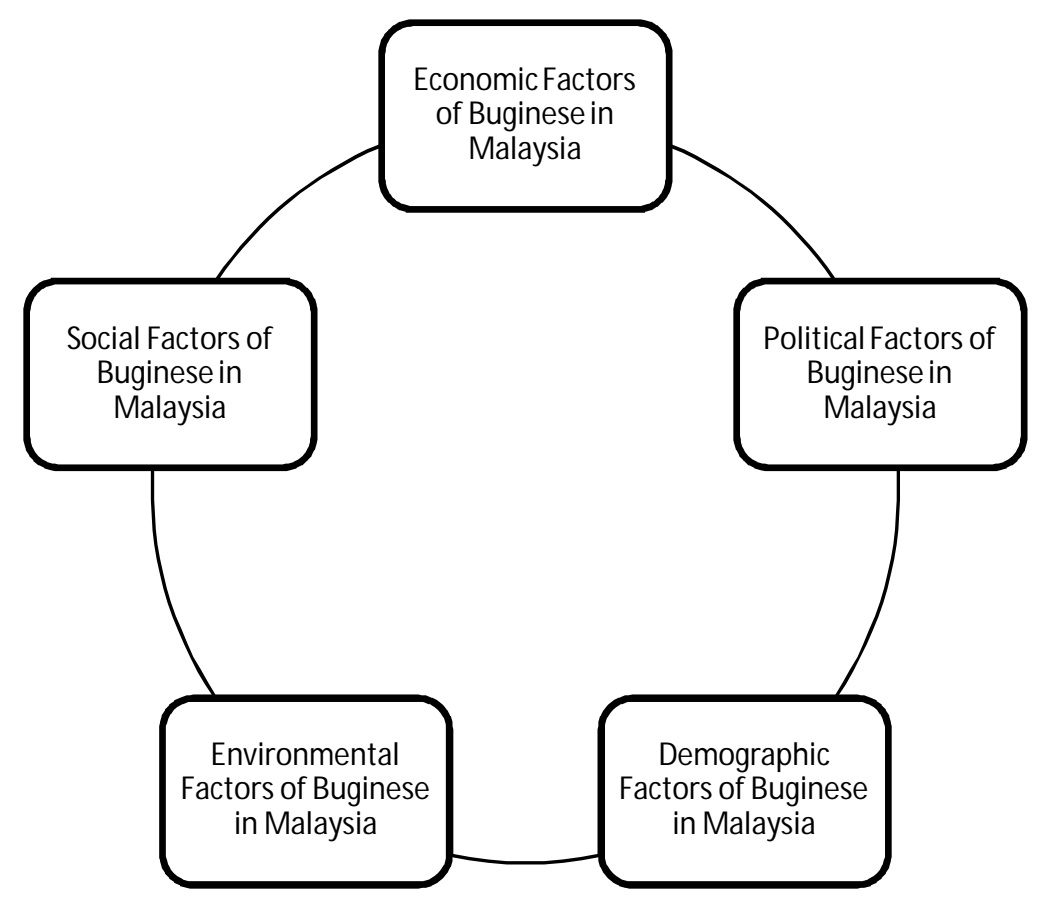

Figure 3. Factors of Migration towards Bugis Diaspora in Malaysia

Economic factors are the factors that affect the migration of Bugis become diaspora and work in Malaysia is the first. This is related to employment opportunity, income and salary. Employment opportunities in some areas in South Sulawesi have become increasingly narrow, this is due to the shifting of paradigm in employment recruitment. The Bugis who used to work as traders and farmers lost their jobs, so that they were motivated to seek a better livelihood outside their home areas and be encouraged by their philosophical beliefs, so there are those who choose to work in Malaysia, mainly on the Palm plantation.

Political factors also influence the migration process. Government policy during the New Order era that encouraged transmigration from Celebes island to Borneo island made the Bugis leave their homeland and migrate to new places. The policy is getting closer to the Bugis tribe with Malaysia, in addition to Bugis tribe originating from South Sulawesi, Bugis tribes who live in Kalimantan also migrate to Malaysia to get a better livelihood. In addition, 
because the Bugis diaspora also in Malaysia, especially in Sabah is quite influential as a trader as well as various vital professions in society, the Malaysian policy also sided with the Bugis contribution for the region.

Demographic factors contribute to the third factor affecting migration. Low-skilled workers are the problem of Indonesia as a sending country, causing Indonesian migrant workers to have problems in Malaysia. In addition, the data already mentioned that the number of illegal migrant workers are also high, so it is necessary to curb illegal migrant workers and also increase the capacity of Indonesian migrant workers, especially those from South Sulawesi in order to optimize their working in the placement country.

The family factor is the fourth factor driving the migration of the Bugis to Malaysia. The size of the Bugis society in Malaysia, especially Sabah, also contributes to migration. One of the informants, Researcher met during a research in Tawau, Sabah, Malaysia stated that he came from one of the areas in South Sulawesi to Malaysia to follow his uncle's suggestion to work in a palm plantation. This shows that family invitation factor is one of the driving factors. In addition, cultural and language similarity between Malaysia and Indonesia is one of the driving forces. Some Bugis diaspora in Malaysia have even produced second and third generation Bugis tribes in Malaysia who can not even speak Bugis anymore and even not come to the birthplace of their ancestors.

Environmental factors are the fifth and last factor can be a driver. Drought that hit some areas in South Sulawesi happened and caused rice fields farmers can not be planted. This encourages migration to Malaysia to visit their families, while seeking employment opportunities. Although it is understandable that this is a natural thing, but it is the source of the illegal migrant workers, because the entry of Indonesians seeking employment to Malaysia without going through the procedures established by the government, then other problems follow their presence in Malaysia, one of the threats in deportation back to Indonesia.

Susilowati, Rahardjo and Waridin (2001), identifying factors of marital status and length of stay in the destination country are the main factors affecting IMW, including Bugis. Marital status even marriage with Malaysian becomes a factor that even makes Indonesian settled in Malaysia. The length of stay that exceeds the time limit that has been established causes the status of Indonesian citizens in trouble, this triggers Indonesians to become illegal in Malaysia. Other factors of income earned in destination countries are factors that also attract Indonesians to Malaysia. While overseas work experience becomes a factor that can 
attract interest or discourage the intention because the experience felt by each person is different.

Based on the above explanation it can be understood that the existence of the Bugis diaspora in Malaysia was later suspected to be the trigger of another Bugis migrants with one of the reasons to look for a job. The existence of the Bugis society in Malaysia affected by the five factors that have been described, ranging from the increasingly narrow employment in South Sulawesi that encouraged the desire to work abroad to get a better life, then the government's transmigration policy during the New Order era encouraged Bugis migration to Borneo island getting closer to the Malaysian border and continuing from Borneo to Malaysia and the Bugis diaspora position in Malaysia, especially in Sabah quite influential so that Malaysian policy in favor of Bugis tribe.

In addition, problems arise from low-skilled workers from Indonesia sent to Malaysia. The data also shows that the number of illegal workers is also high, so it is necessary to increase the capacity of IMW, especially from South Sulawesi in order to optimize its working time in the placement country. Furthermore, the Bugis society in Malaysia, especially Sabah and family invitations in Malaysia to the family members in the origin (South Sulawesi) became the driver of migration. The cultural and language similarity between Malaysia and Indonesia is also a contributing factor. Finally, unpredictable natural conditions, even droughts in some areas cause livelihoods as farmers can not be done. Thus, they choose to seek employment through family members in Malaysia, and this is one source of violation, due to their entry into Malaysia without going through procedures established by the government.

\section{Conclusions}

This study concludes that the presence of Bugis diaspora in Malaysia present the dynamics in the development of Indonesian migrant workers, mainly from South Sulawesi, Indonesia to Sabah Malaysia. The close relationship of kinship brings the PATI or Unauthorized Foreign Migrants. This should be a concern of the Indonesian government to make effective policies and regulations that have been made to prevent and combat violations by Indonesian citizens in the work migration process. In addition, optimizing the protection for Indonesian citizens, including Indonesian migrant workers who are migrating to work in the placement country, primarily Malaysia. 


\section{Acknowledgement}

The authors express the highest appreciation to the Indonesia Endowment Fund for Education/Lembaga Pengelola Dana Pendidikan (LPDP), Ministry of Finance of the Republic of Indonesia for research funds provided through Thesis and Dissertation Scholarship Batch 1 Year 2016 with the contract Number: PRJ-507/LPDP.3/2016 for the writing of my thesis in Master of Political Sciences Universitas Hasanuddin entitled "Analisis Ekonomi Politik Pemenuhan Hak-Hak Pekerja Migran asal Sulawesi Selatan di Malaysia". Thank you for the guidance from Prof. Dr. Muh. Kausar Bailusy, M.A. and Dr. Gustiana A. Kambo, M.Si. that help author to produce this monumental work aimed at the progress of the Indonesian nation in the field of Indonesian Migrant Workers' Placement and Protection.

\section{Reference}

Antara News, (2013), Kemlu bentuk 11 Kelompok Kerja Kongres Diaspora http://www.antaranews.com/berita/384634/kemlu-bentuk-11-kelompok-kerja-kongresdiaspora, diakses pada 19 Desember 2016.

Anwar, O. M. (2016). Contextualizing nusantara studies. Journal of Nusantara Studies, 1(1), $1-6$.

Black, R., Kniveton, D., \& Schmidt-Verkerk, K. (2011). Migration and climate change: Towards an integrated assessment of sensitivity. Environment and Planning, 43, 431-450.

Bustami, Reevany, Suyatno \& Ismail Suardi Wekke. Migrants in Nusantara: Indonesian and Malaysian Perspectives. Journal of Nusantara Studies 2016, Vol 1(2) 63-74.

Cohen, M.J., \& Lemma, M. (2011). Agricultural extension services and gender equality, an institutional analysis of four districts in Ethiopia. International Food Policy Research Institute Discussion paper 01094.

Dana, E. H. (2012). Understanding rural-to-urban migration in Ethiopia: Driving factors, analytical frameworks, and recommendations. Journal of Global Health Perspectives, 2(1), 12-31.

Eriksen S., Brown K., \& Kelly P.M. (2005). The dynamics of vulnerability: Locating coping strategies in Kenya and Tanzania. Geographical Journal, 171, 287-305.

Government Office for Science London (2011). Foresight: Migration and global environmental change. Retrieved from https://www.gov.uk/government/uploads/system/uploads/attachment_data/file/287717/111116-migration-and-global-environmental-change.pdf

International Organization for Migration (IOM). (2010). Labour migration from Indonesia: An Overview of Indonesian Migration to Selected Destinations in Asia and the Middle East. Jakarta: IOM.

Kanapathy, V. (2008). Controlling Irregular Migration: The Malaysian experience. Bangkok: ILO.

Mansyur. Diaspora Suku Bugis dan Terbentuknya Identitas To-Ugi' di Wilayah Tanah Bumbu, Residensi Borneo Bagian Selatan dan Timur, Tahun 1900-1942 
Sugiyarto, Guntur. (2014). Internal and international migration in Southeast Asia. In Ian Coxhead (ed.), Routledge Handbook of Southeast Asian Economics (pp 1-28). New York: Routledge.

Susilowati, Indah, Mudji Rahardjo dan Waridin. (2001). Analisis Masalah Sosial, Politik dan Ekonomi pada Migrasi Tenaga Kerja Indonesia ke Luar Negeri, Laporan Penelitian DCRG, Universitas Diponegoro.

Tacoli, C. (2009). Crisis or adaptation? Migration and climate change in a context of high mobility. Environment and Urbanization, 21(2), 513-525.

United Nations, (2012), Secretary-General's Report on International Migration and Development - http://daccess-ods.un.org/TMP/500607.416033745.html

Wekke, I. S. (2013). Masjid di Papua Barat: Tinjauan ekspresi keberagamaan minoritas Muslim dalam arsitektur. El-Harakah Jurnal Budaya Islam, 15(2), 124-149.

Wekke, I. S. \& Suyatno. (2015). The Case of Bugis and Madura in the Eastern Indonesia. Paper presented in International Workshop on Migration and Cohesion in Multi-ethnic Societies: Irregular Immigration, Nusantara Heritage, and Justice. Malaysia: CenPRIS, Universiti Sains Malaysia.

Wekke, I. S. (2016). Arabian society in Kaili lands, central Sulawesi: Arabic education and its movement. Tawarikh, 7(1), 63-74.

Zulfikar, Achmad. (2016), Analisis Ekonomi Politik Pemenuhan Hak-Hak Pekerja Migran asal Sulawesi Selatan di Malaysia. Tesis. Makassar: Universitas Hasanuddin. 